\title{
Simulating cancer cell growth and effect of chemotherapy on cancer cells
}

\begin{abstract}
In order to simulate cancer growth rate, travelling wave migration effects and effects of chemotherapy on given initial number of cancer cells, the following calculations have been done to estimate the effectiveness of the dosage of chemotherapy. Using this method any appropriate function could be used to estimate cancer growth, cancer travelling wave migration and chemotherapy.
\end{abstract}

Keywords: growth rate, travelling wave migration, chemotherapy
Volume 9 Issue 3 - 2018

Saeid Parsa

Retired researcher, Materials and energy research center, Iran

Correspondence: Saeid Parsa, Material and Energy Research Center, Tehran, I.R. Iran, Email: saeidparsa2004@gmail.com

Received: April 04, 2018 | Published: May II, 2018

\section{Method of calculations}

Cancer cell growth, and effect of different treatments on cancer tumors, is mainly effected by many functions; growth function, migration wave function, chemotherapy function, and radiotherapy function. To treat cancer patients depending where the tumor is, the tumor removed by operation and radiotherapy is performed and if necessary chemotherapy is done.

Cancer cells growth function

Cancer cells growth is given by following equation. ${ }^{1}$
The number of grown cancer cells $=\mathrm{N}_{0} * \exp \left(\ln \left(\mathrm{N}_{\max } / \mathrm{N}_{0}\right) *(1-\exp (-\right.$ $\ln (4) * \mathrm{i}))), \mathrm{i}=1, \ldots \ldots$, number of days,

Where: $\mathrm{N}_{0}=$ estimated initial cancer cells per area under investigation.

$\mathrm{N}_{\max }=$ maximum of cells in the area.

The table below is indicating the growth of cancer cells during five days with the given initial cancer cells to start with:

The below table is written for five days and the average value is also calculated.

\begin{tabular}{|c|c|c|c|c|c|c|c|c|c|c|c|c|c|}
\hline 10 & 15 & 20 & 25 & 30 & 35 & 40 & 45 & 50 & 55 & 60 & 65 & 70 & نى \\
\hline 0.31623 & 0.4743416 & 0.37606 & 0.397635 & 0.416179 & 0.4325308 & 0.447214 & 0.460578 & 0.472871 & 0.48427 & 0.49492 & 0.50493 & 0.514369 & 0.43272 \\
\hline 0.74989 & 0.7691405 & 0.783095 & 0.794093 & 0.803193 & 0.810969 & 0.817765 & 0.823808 & 0.834205 & 0.8342 & 0.83875 & 0.84296 & 0.84296 & 0.80451 \\
\hline 0.93057 & 0.9364863 & 0.940705 & 0.943991 & 0.946684 & 0.9489669 & 0.950949 & 0.952701 & 0.95427 & 0.95569 & 0.95699 & 0.95819 & 0.95819 & 0.94678 \\
\hline 0.98217 & 0.9837287 & 0.984835 & 0.985694 & 0.986396 & 0.987505 & 0.987505 & 0.987959 & 0.988366 & 0.98873 & 0.98907 & 0.98938 & 0.989666 & 0.98647 \\
\hline 0.99551 & 0.9959071 & 0.996187 & 0.996404 & 0.996581 & 0.9967315 & 0.996862 & 0.996976 & 0.997079 & 0.99717 & 0.99726 & 0.99733 & 0.997406 & 0.99659 \\
\hline
\end{tabular}

The below table shows normalized mean for each day multiplied by number of cells and accumulated to give the total number of cells at the end of five day periods.

\begin{tabular}{|c|c|c|c|c|c|}
\hline Day & Mean normalized & Number of cancer cells $=10$ & Number of cancer cells $=100$ & Number of cancer cells $=1000$ & Number of cancer cells $=10000$ \\
\hline 1 & 0.103842275 & 11.03842275 & 110.3842275 & 1103.842275 & 11038.42275 \\
\hline 2 & 0.193064018 & 12.96906294 & 129.6906294 & 1296.906294 & 12969.06294 \\
\hline 3 & 0.22720584 & 15.24112134 & 152.4112134 & 1524.112134 & 15241.12134 \\
\hline 4 & 0.236729293 & 17.60841427 & 176.0841427 & 1760.841427 & 17608.41427 \\
\hline \multicolumn{2}{|c|}{ sum of cells after five days } & 76.8570213 & 768.570213 & 7685.70213 & 76857.0213 \\
\hline
\end{tabular}

In order to investigate the effectiveness of chemotherapy the following formula is introduced by reference. ${ }^{1}$

Number of effected cells by chemotherapy=number of effected cells*exp (-BSA).

The body surface area (BSA) is the measured or calculated surface area of a human body. For many clinical purposes BSA is a better indicator of metabolic mass than body weight because it is less affected by abnormal adipose mass. Nevertheless, there have been several important critiques of the use of BSA in determining the dosage of medications with a narrow therapeutic index, such as chemotherapy.

Different formula is suggested for calculation of BSA which is tabulated in Table 1. The following formula is used during our calculations. 
Table I Body Surface Area formulae used for the comparison.

\begin{tabular}{|c|c|}
\hline Authors & Formula \\
\hline Meeh (1879) & $0.1053 \cdot \mathrm{W}^{2 / 3}$ \\
\hline DuBois \& DuBois (1916) & $0.007184 \cdot W^{0.425} \cdot H^{0.725}$ \\
\hline Faber \& Melcher (1921) & $0.00785 \cdot W^{0.425} \cdot H^{0.725}$ \\
\hline Takahira (1925) & $0.007246 \cdot W^{0.425} \cdot H^{0.725}$ \\
\hline Breitmann (1932) & $0.0087 \cdot(\mathrm{W}+\mathrm{H})-0.26$ \\
\hline $\begin{array}{l}\text { Boyd (1935) } \\
\text { Stevenson (1937) }\end{array}$ & $\begin{array}{l}0.0003207 \cdot(W \cdot 1000)^{0.7285-0.0188 \cdot \log } 1{ }^{(W \cdot 1000)} \cdot H^{0.3} \\
0.0128 \cdot \mathrm{W}+0.0061 \cdot \mathrm{H}-0.1529\end{array}$ \\
\hline Sendroy \& Cecchini (1954) & $0.0097 \cdot(\mathrm{W}+\mathrm{H})-0.545$ \\
\hline Banerjee \& Sen (1955) & $0.007466 \cdot W^{0.425} \cdot H^{0.725}$ \\
\hline Choi (1956) & $\begin{array}{l}\text { men: } 0.005902 \cdot W^{0.407} \cdot H^{0.776} \\
\text { women: } 0.008692 \cdot W^{0.442} \cdot H^{0.678}\end{array}$ \\
\hline Mehra (1958) & $0.01131 \cdot W^{0.4092} \cdot H^{0.6468}$ \\
\hline Banerjee \& Bhattacharya (1961) & $0.007 \cdot W^{0.425} \cdot H^{0.725}$ \\
\hline Fujimoto et al. (1968) & $0.008883 \cdot W^{0.444} \cdot H^{0.663}$ \\
\hline Gehan \& George (1970) & $0.0235 \cdot W^{0.51456} \cdot H^{0.42246}$ \\
\hline Haycock et al. (1978) & $0.024265 \cdot W^{0.5378} \cdot H^{0.3964}$ \\
\hline Mosteller (1987) & $\sqrt{(W \cdot H / 3600)}$ \\
\hline Mattar (1989) & $(\mathrm{W}+\mathrm{H}-60) / 100$ \\
\hline Nwoye (1989) & $0.001315 \cdot W^{0.262} \cdot H^{1.2139}$ \\
\hline Shuter \& Aslani (2000) & $0.00949 \cdot W^{0.441} \cdot H^{0.655}$ \\
\hline Livingston \& Lee (2001) & $0.1173 \cdot W^{0.6466}$ \\
\hline Tikuisis (2001) & $\begin{array}{l}\text { men: } 0.01281 \cdot W^{0.44} \cdot H^{0.6} \\
\text { women: } 0.01474 \cdot W^{0.47} \cdot H^{0.55}\end{array}$ \\
\hline Nwoye \& Al-Sheri (2003) & $0.02036 \cdot W^{0.427} \cdot H^{0.516}$ \\
\hline Yu, Lo, Chiou (2003) & $0.015925 \cdot(W \cdot H)^{0.5}$ \\
\hline Schlich (2010) & $\begin{array}{l}\text { men: } 0.000579479 \cdot W^{0.38} \cdot H^{1.24} \\
\text { women: } 0.000975482 \cdot W^{0.46} \cdot H^{1.08}\end{array}$ \\
\hline Yu, Lin, Yang (2010) & $0.00713989 \cdot W^{0.404} \cdot H^{0.7437}$ \\
\hline
\end{tabular}

Schlich (2010) men: $0.000579479 \cdot W^{0.38} \cdot H^{1.24}$ women: $0.000975482 \cdot W^{0.46} \cdot H^{1.08}$

$\mathrm{W}=$ patient weight in kilogram.

$\mathrm{H}=$ patient height in centimeters.

Simulating the cancer growth and migration with following initial values will give the following results:

$\mathrm{N}_{0}=$ initial cancer growth cells $=100$

$\mathrm{N}_{\max }=20000$

Body surface area $=2.21$

Weight $=106 \mathrm{~kg}$ 


\section{Height $=178 \mathrm{~cm}$}

$\mathrm{N}_{3}=$ initial number of migration cells $=10$ cells

The below table indicates the number of effected cells by chemotherapy:

\begin{tabular}{lcccc}
\hline $\begin{array}{l}\text { Number of cells } \\
\text { after chemotherapy }\end{array}$ & 169.85402 & 1698.54 & 16985 & 169854 \\
$\begin{array}{l}\text { A given } \\
\text { BSA }=2.196653612\end{array}$ & 168.828 & 1688.28 & 16883 & 168828 \\
\hline
\end{tabular}

Of course there is another problem associated to traveling wave function which is the rate of migration of cancer cells from main organ to other organs. This migration is usually associated to blood circulation and Lymphatic system.

$$
\begin{aligned}
& U^{\prime}=\frac{1}{4}\left(e^{-x}+e^{x}\right)+e^{-x} \\
& U=\frac{1}{4}\left(e^{x}-3 e^{-x}\right) \\
& N_{3}=\text { number migrating cells. } \\
& x=\text { Body surface area } .
\end{aligned}
$$

\begin{tabular}{ll}
\hline $\mathrm{U}$, traveling wave function value $=$ & 2.19665 \\
Number of cancer cells & Number of migration \\
10 & 21.9665 \\
100 & 219.665 \\
1000 & 2196.65 \\
10000 & 21966.5 \\
\hline
\end{tabular}

According to growth of cancer cells and BSA the physician has to prescribe the chemotherapy.

\section{Body Surface Area formulae used for the comparison.}

$W$ indicates weight in kilograms, and $H$ indicates height in centimeters.

Dose $=$ Weight $*$ SeverityFactor $*$ RenalFactor

\section{Iron Replacement (parenteral dosing) for Iron Deficiency \\ Dose $=0.3 *$ Weight $*(100-(\mathrm{Hgb} * 100) /$ AgeFactor $)$}

\section{Radiation therapy}

Radiotherapy uses high energy radiation to shirink tumor and kills cancer cells. X-rays, gamma rays, and particles are types of radiations used for cancer treatment. The radiation may be delivered by a machine outside the body, or it may come from radioactive sources situated near the cancer tumor, or it may be given in form of oral medications to patients and x-ray treatment is then used, depending where is the body the tumor cancer is located.

Radiotherapy kills cancer cells by damaging their DNA and therefore cells, cancer cells whose DNA is damaged beyond repair stop dividing or die, when the damage cells die, they are broken down and eliminated by the bodies natrual process, radiation therapy can also damage normal cells, making the patient ill in some cases. In order to find the right position near the cancer tumor and its surroundings cells, depending on the organ the proper scan; CT scan, MRI, PET scan or sonography. After simulation, placing the cancer tumor area. Amount radiotherapy dose is determined and treatment is started and required dose is delivered to the cancer tumor.

\section{Chemotherapy}

Chemotherapy is done through blood transfusion using different medicine during period of time depending on cancer spration and its location.

\section{Acknowledgements}

None.

\section{Conflict of interest}

Author declare there is no conflict of interest in publishing the article

\section{References}

1. Enderling H, Chaplain MA. Mathematical Modeling of Tumor Growth and Treatment. Curr Pharm Des. 2014;20(30):4934-40. 